\title{
Asymmetric seasonal nest site competition between Great Tits and House Sparrows
}

\author{
Motti Charter · Yossi Leshem · Ido Izhaki
}

Received: 16 March 2012/Revised: 6 June 2012/ Accepted: 12 July 2012 / Published online: 22 August 2012

(C) Dt. Ornithologen-Gesellschaft e.V. 2012

\begin{abstract}
Using nest boxes with different sized entrances, we experimentally examined whether a large species of cavity breeder (House Sparrow, Passer domesticus) affects the nest box occupancy and breeding success of a smaller species (Great Tit, Parus major), and whether there are differences in the effects of competition during different parts of the breeding season. Great Tits occupied nest boxes regardless of the number of House Sparrows breeding in the vicinity. During the second part of the breeding season, the percentage of successful Great Tit pairs was negatively correlated with the occupation of nest boxes by the House Sparrows, in both the large- and smallentrance nest boxes. More Great Tit pairs bred and more young were fledged in the small- than large-entrance nest boxes. Great Tits occupied more large-entrance nest boxes during the first than the second part of the breeding season. This difference was probably due to House Sparrows occupying more large-entrance nest boxes during the second than first part of the breeding season. $74 \%$ of the large-entrance nest boxes in which Great Tits built nests in both the first and second parts of the season were later
\end{abstract}

Communicated by T. Friedl.

M. Charter $(\bowtie) \cdot$ Y. Leshem

Zoology Department, Tel-Aviv University,

69978 Ramat-Aviv, Tel-Aviv, Israel

e-mail: charterm@post.tau.ac.il

Present Address:

M. Charter · I. Izhaki

Department of Evolutionary and Environmental Biology,

University of Haifa, 31905 Haifa, Israel

M. Charter

Department of Ecology and Evolution, Biophore,

University of Lausanne, 1015 Lausanne, Switzerland occupied by House Sparrows. Great Tits preferred largeentrance nest boxes in the fall, when House Sparrows use only a few boxes for roosting, but not for breeding. The findings indicate that Great Tits are subject to interspecific competition with House Sparrows for nesting cavities, the intensity of which varies during the breeding season and is higher during the second part when more House Sparrows breed.

Keywords Cavity - Breeding success - Experimental study $\cdot$ Nest box

\section{Zusammenfassung}

Asymmetrische saisonale Nistplatzkonkurrenz zwischen Kohlmeise Parus major und Haussperling Passer domesticus

Mit Hilfe von Nistkästen mit unterschiedlich großen Öffnungen untersuchten wir experimentell, ob eine große höhlenbrütende Art (Haussperling, Passer domesticus) die Besetzung von Nistkästen durch eine kleinere höhlenbrütende Art (Kohlmeise, Parus major) und deren Bruterfolg beeinflusst und ob es Unterschiede in den Effekten der Konkurrenz zu verschiedenen Zeiten der Brutsaison gibt. Kohlmeisen besetzten Nistkästen unabhängig von der Zahl der in der Nähe brütenden Haussperlinge. Während des zweiten Teils der Brutsaison war der Anteil von erfolgreichen Kohlmeisen-Paaren negativ korreliert mit der Besetzung von Nistkästen durch den Haussperling, und zwar sowohl in Nistkästen mit großen als auch kleinen Eingangsöffnungen. In den Nistkästen mit kleinen Eingangsöffnungen brüteten mehr Kohlmeisenpaare und mehr Jungvögel wurden flügge als in den Kästen mit großer Eingangsöffnung. Kohlmeisen besetzten im ersten 
Teil der Brutsaison mehr Nistkästen mit großer Eingangsöffnung als im zweiten Teil. Dieser Unterschied kam wahrscheinlich dadurch zustande, dass Haussperlinge im zweiten Teil der Brutsaison mehr Nistkästen mit großer Eingangsöffnung besetzten als im ersten. $74 \%$ der Nistkästen mit großer Eingangsöffnung, in denen Kohlmeisen sowohl im ersten als auch zweiten Teil der Brutsaison nisteten, wurden später von Haussperlingen besetzt. Kohlmeisen bevorzugten im Herbst Nistkästen mit großer Eingangsöffnung, wenn Haussperlinge nur wenige Kästen zum schlafen nutzen, aber nicht zum brüten. Die Ergebnisse deuten darauf hin, dass Kohlmeisen mit Haussperlingen in einer interspezifischen Konkurrenz um Bruthöhlen stehen, deren Intensität sich im Verlauf der Brutsaison ändert und im zweiten Teil größer ist, wenn mehr Haussperlinge brüten.

\section{Introduction}

During the past couple of decades, interspecific competition has received much attention as an important ecological phenomenon (Menge and Sutherland 1976; Schoener 1983; Maurer 1984; Keddy 1989; Wiens 1989). Birds may compete over several resources, such as food, roosting areas and nest sites (Gustafsson 1987; Loeb and Hooper 1997; Dhondt and Adriaensen 1999; Dhondt 2010). A wellstudied example of such competition is that of the Great Tit (Parus major) and Blue Tit (Cyanistes caeruleus) (Dhondt and Adriaensen 1999). During the breeding season, Blue Tits were found to have a negative effect on the larger Great Tit, through exploitation competition for food (Dhondt 1977; Minot 1981). However, when nest sites were lacking, the larger Great Tits were more successful in occupying a nest cavity (Minot and Perrins 1986). In comparison, during the winter, Great Tits more successfully occupied roost cavities than Blue Tits through interference competition (Dhondt and Eyckerman 1980). Even though a difference in both the occupation of nest sites and in reproductive success was reported for the two species (Dhondt and Adriaensen 1999; Dhondt 2010), it is difficult to determine the specific cause of competition because these two species compete for both food and nest sites. Thus, there is still a need to study species that compete only for nest sites, but not for food, in order to better understand the consequences of nest site competition on breeding success of both species.

Some potential competing species initiate breeding at different times, with earlier breeders having the first pick of cavities and the potential to exclude later breeders (Slagsvold 1978; Gustafsson 1988). This is only the case, however, when the earlier breeder can defend the nest from later breeders (e.g. a larger species can arrive later and evict the smaller species). The size of the nest entrance can determine what species of secondary cavity breeders will be able to enter, with smaller entrances excluding certain larger species (Löhrl 1977; Dhondt and Eyckerman 1980; Dhondt and Adriaensen 1999). During the competition for nest holes, smaller species are sometimes killed by larger competing species (Merilä and Wiggins 1995). During the winter, if only large entrances are available, small species may thus avoid them entirely, even though many cavities remain available (Dhondt and Eyckerman 1980).

Most studies on competition in birds have dealt with woodland birds (Löhrl 1977; Dhondt and Eyckerman 1980; Minot and Perrins 1986; Gustafsson 1988). Rapid urbanisation has become an area of concern in conservation due to the massive alteration of land use (Miller and Hobbs 2002). Urban landscapes reveal different species' richness, abundance, diversity of bird communities, and a lack of nest cavities compared to woodland (Blair 1996; Germaine et al. 1998; Cam et al. 2000; Reynaud and Thioulouse 2000; Clergeau et al. 2001; Crooks et al. 2004). Indeed, most studies on urban ecology have engaged with the consequences of competition in terms of changes in species abundance and diversity (Marzluff 2001), rather than studying interspecific competition. As many invasive species, some of which are cavity breeders, flourish in urban areas, there is a need for an experimental approach (Strubbe and Matthysen 2009) in order to better understand the issue of competition over nest sites.

We examined a system of the two smallest native secondary cavity breeding passerine species in Israel, which may compete for nest sites in rural residential gardens, the smallest of which (Great Tit, $18 \mathrm{~g}$ ), initiates breeding earlier than the larger species (House Sparrow, Passer domesticus, 29 g) (Yavin 1987; Charter et al. 2010a). However, the Great Tit may be susceptible to eviction when the latter begins to breed. Little is known on how Great Tits, which are considered successful cavity competitors in many parts of Europe, compete with larger species for nest holes (van Balen et al. 1982).

In orange groves in Spain, Barba and Gil-Delgado (1990), over a 3-year observational study, found that Great Tits occupied fewer nest boxes, and suggested that this was due to an increase in House Sparrows and black rats occupying the nest boxes. In that study, annual variations in weather or food, as well as predation by rats, may also have affected the Great Tit populations, rather than competition. At our study site in Israel, Great Tit and House Sparrow diets differ, with House Sparrows being largely granivorous and Great Tits largely insectivorous. Even though House Sparrows may also feed their young on some insects, the location in which the two species forage is different: House Sparrows forage on the ground and Great 
Tits mainly on bushes and trees. Therefore, any differences found in breeding success are most likely to have been caused by competition over nest sites and not over food.

There are two possible ways to study competition experimentally: by manipulating the abundance of competitors, and by manipulating the limiting resource (Dhondt and Adriaensen 1999). In this study, we manipulated nest boxes by changing the size of the nest entrance and thereby limiting access by the larger competitors (House Sparrows) to some nest boxes, in order to determine whether larger competitors limit the breeding of smaller species (Great Tits).

Based on our preliminary field observations, we posited two hypotheses: (1) Great Tits will mainly occupy nest boxes with small entrances and avoid the nest boxes with large entrances in order to reduce competitive interaction with the larger sparrows; and (2) competition between the two species will become more intense during the second part of the breeding season, when both species are breeding, than in the first part of the breeding season when only the Great Tits breed.

\section{Methods}

\section{Study site}

The study site was located in in the Jezreel Valley, Israel $\left(32^{\circ} 31^{\prime} 55^{\prime \prime} \mathrm{N}, 35^{\circ} 15^{\prime} 25^{\prime \prime} \mathrm{E}\right), 80-90 \mathrm{~m}$ above sea level, with a semi-arid climate $(453 \mathrm{~mm}$ annual rain; maximum and minimum mean daily temperatures of 27.8 and $15.2{ }^{\circ} \mathrm{C}$, respectively, during March through July (Michael Hyman, personal communication).

The 65-ha study site hosted 680 residents and 170 houses (up to 2 floors) each with a $500-\mathrm{m}^{2}$ garden and additional small storage buildings. The built-up area is surrounded by agriculture, mainly fields of sweet corn, alfalfa, oats and wheat, grape vines, almond plantations and olive groves.

\section{Experimental set-up}

Nest boxes $(n=161)$, were constructed from untreated plywood $(15 \mathrm{~cm} \times 15 \mathrm{~cm} \times 24 \mathrm{~cm}, \mathrm{~W} \times \mathrm{L} \times \mathrm{H}$, wall thickness $17 \mathrm{~mm}$ ) and placed $40-50 \mathrm{~m}$ apart on trees at a height of 1.5-2.0 m. All the nest boxes had an internal entrance size of $50 \mathrm{~mm}$, However, the external entrance holes could be adjusted to a size of either $50 \mathrm{~mm}$ or $28 \mathrm{~mm}$ using a small metal plate glued to the front of each nest box. Consequently, there was no difference in the internal height of the different entrance holes from the bottom of the nest. Nestlings were able to reach the entrance hole of both entrance types in a similar manner. Great Tits could enter both sized entrance nests whereas House Sparrows could enter only the larger 50-mm nest entrances. Even though in Europe Great Tits breed in a $32-\mathrm{mm}$ entrance size more than in 28-mm entrances (Hedblom and Söderström 2012), in Israel, we had found that, while some House Sparrows could enter nest boxes with an entrance of 29 or $30 \mathrm{~mm}$, none were able to enter those with an entrance of $28 \mathrm{~mm}$, whereas Great Tits were able to enter and breed in both (Charter, unpublished data). If Great Tits breed in nest boxes with $28-\mathrm{mm}$ entrances more than larger entrance nest boxes, this is most likely due to pressure by House Sparrows and not to a preference for smaller entrance sizes.

The experiment comprised four treatments (Fig. 1): (1) nest boxes with large entrance $(50 \mathrm{~mm}$, hereafter, $\mathrm{L}$, $n=40$ ); (2) nest boxes with small entrance ( $28 \mathrm{~mm}$, hereafter S, $n=41$ ); (3) nest boxes for which at the beginning of the breeding season the entrance was small (28 mm), but on March 16, 2009, the metal entrance plates were exchanged for the larger $(50 \mathrm{~mm})$ entrance (hereafter SL, $n=40$ ); and (4) nest boxes that in the beginning of the breeding season the entrance was large $(50 \mathrm{~mm})$, but on March 16, 2009, the metal entrance plates were exchanged for the smaller $(28 \mathrm{~mm}$ ) entrance (hereafter LS, $n=40$ ). To control for experimental manipulation, the $\mathrm{S}$ and $\mathrm{L}$ treatments were also exchanged with same-sized metal plates on March 16 in all the other boxes. The nest contents were left intact when the entrance hole plates were changed. None of the House Sparrows occupying nest boxes whose entrances were reduced from $\mathrm{L}$ to $\mathrm{S}$ had begun laying eggs (all were in various stages of nest building).

The four experimental treatments were grouped into 34 blocks (some boxes were on the border of the study site and are not included in this analysis) using randomized block design, where each block contained one nest box each from the control S, control L, SL and LS groups (Fig. 1). We

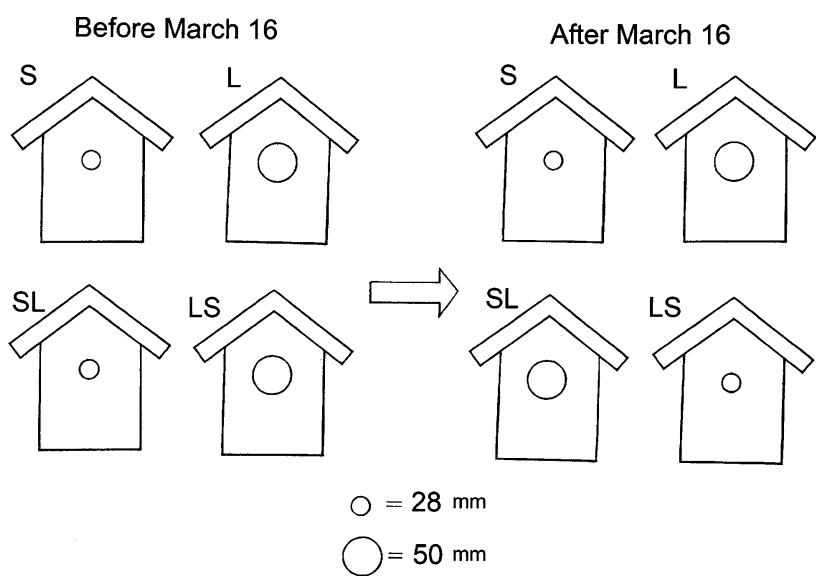

Fig. 1 The experimental set-up comprised two control nest boxes ( $S$ and $L$ ) and two experimental treatment nest boxes ( $S L$ and $L S$ ), whose entrance sizes were exchanged on March 16 (drawing: Tuvia Kurtz) 
used a randomized block design because the breeding of Great Tit and House Sparrow may vary between breeding sites and habitats (Chamberlain et al. 2007; Hedblom and Söderström 2012), and the randomized block design accommodates spatial environmental heterogeneity and improves statistical power (Scheiner and Gurevitch 2001). We examined whether the presence of House Sparrows in the blocks affected Great Tit occupation and success in the large-entrance ( $\mathrm{L}+\mathrm{LS}$ nest boxes before; $\mathrm{L}+\mathrm{SL}$ after) and small-entrance $(\mathrm{S}+\mathrm{SL}$ nest boxes before; $\mathrm{S}+\mathrm{LS}$ after) nest boxes before and after March 16. In every randomized block, there were two large- or two small-entrance nest boxes used to determine the breeding parameters of the Great Tits.

All nest boxes were visited twice during autumn 2008 (once each during October and November) and weekly during spring 2009 (from February 1 to July 1). We recorded all breeding attempts (defined as nest boxes in which nests were built) made by Great Tits and House Sparrows. Even nests abandoned in the earliest stage of building could be identified according to species, because House Sparrows and Great Tits use very different nest materials. In addition, we recorded for Great Tits whether pairs had laid eggs and succeeded (fledged at least one young), number of young hatched (brood size), and number of young fledged. The following were also calculated: laying date (assuming females laid one egg per day until clutch completion, laying date was also calculated for House Sparrows); hatching success as the percentage of eggs that hatched within each clutch; fledging success as the percentage of young that fledged from each brood for all pairs that hatched at least one egg; brood size per breeding attempt (number of young at hatching); number of young fledged per breeding attempt (number of young at banding, 12-14 days minus any dead found in the box); and the number of young per successful nest, defined as a nest that produced at least one chick that fledged. Some clutch sizes could not be observed because the females were present during the experimenter's visit to the nest boxes. Breeding data were recorded for each breeding attempt unless stated otherwise. During the study, at least one adult was banded in almost all the nests. Only two nest boxes were used twice and in both cases it was used by the same pair. Only the first breeding attempt was noted in the analysis. Nests were not removed after breeding had ended.

\section{Statistical analyses}

All statistical tests were two-tailed. Descriptive breeding data were analyzed using the $t$ test and the Mann-Whitney $U$ test. Spearman's test was used to analyse correlations among breeding parameters, and the $z$ test for two proportions was used to compare occupation and nest success. Chi-square and Fisher's exact test were used to compare the number of pairs breeding during the two different parts of the breeding season. Levels of significance were set at $P<0.05$. Statistical analyses were performed using SPSS for Windows v.20.

\section{Results}

Patterns of occupancy and breeding success

Great Tits occupied 44 nest boxes $(3 \mathrm{~L}+8 \mathrm{LS}, 15 \mathrm{~S}+$ 18SL) before March 16 and 31 nest boxes (0L $+4 \mathrm{SL}$, $11 \mathrm{~S}+14 \mathrm{LS})$ after March 16. House Sparrows occupied 12 nest boxes $(4 \mathrm{~L}+8 \mathrm{LS}, 0 \mathrm{~S}+$ OSL) before March 16 and 42 nest boxes $(19 \mathrm{~L}+23 \mathrm{SL}, 0 \mathrm{~S}+0 \mathrm{LS})$ after March 16. Mean laying date of first clutches was earlier for Great Tits (March 12, range February 2 to May 17, $\mathrm{SE}=3.8$, $n=44$ ) than House Sparrows (April 15, range March 9 to May 21, $\mathrm{SE}=5.0, n=19$ ) (Mann-Whitney $U$ Test, $z=4.27, P<0.001)$.

Effects of the number of House Sparrows in the area on Great Tit nest box occupation and breeding success

We examined whether the number of House Sparrows in the area affected the number of breeding pairs and breeding parameters of Great Tits in the large-entrance and smallentrance nest boxes in the randomized blocks before and after March 16. The number of nest boxes occupied by House Sparrows in the randomized blocks did not affect the number of Great Tit pairs that attempted breeding in both sized entrance nest boxes before and after March 16 (Table 1). Before March 16, the number of House Sparrows did not affect any of the breeding parameters for smallentrance nest boxes (S and SL nest boxes) in the randomized blocks. However, the number of House Sparrows per block was negatively correlated with the number of Great Tit pairs that succeeded in fledging at least one nestling in the large-entrance nest boxes ( $\mathrm{L}$ and LS nest boxes) (Table 1). After March 16, the number of House Sparrows was negatively correlated (marginally) with the number of Great Tit pairs that succeeded, number of Great Tit young that fledged, and percentage of successful Great Tit pairs in large-entrance nest boxes (L and SL nest boxes). The number of House Sparrows per block was also negatively correlated with the percentage of successful Great Tit pairs per block in small-entrance nest boxes ( $\mathrm{S}$ and LS nest boxes) (Table 1). Great Tits had higher success in nest boxes located in blocks with fewer House Sparrows. 
Table 1 Spearman rank correlations $\left(r_{s}\right)$ of Great Tit (Parus major) breeding parameters in groups according to number of House Sparrows (Passer domesticus) breeding pairs in the Small and Large nest boxes in each randomized block, before and after March 16

\begin{tabular}{|c|c|c|c|c|}
\hline \multirow[t]{2}{*}{ Great Tit breeding parameters } & \multicolumn{2}{|c|}{ Number of sparrows per block before March 16} & \multicolumn{2}{|c|}{ Number of sparrows per block after March 16} \\
\hline & Small entrance $(S+S L)$ & Large entrance $(\mathrm{L}+\mathrm{LS})$ & Small entrance $(\mathrm{S}+\mathrm{LS})$ & Large entrance $(\mathrm{L}+\mathrm{SL})$ \\
\hline Number of Great Tit pairs & $\begin{array}{l}r_{s}=0.03, n=34 \\
P=0.86\end{array}$ & $\begin{array}{l}r_{s}=0.10, n=34 \\
P=0.56\end{array}$ & $\begin{array}{l}r_{s}=0.19, n=34 \\
P=0.29\end{array}$ & $\begin{array}{l}r_{s}=-0.17, n=34 \\
P=0.34\end{array}$ \\
\hline $\begin{array}{l}\text { Number of Great Tit pairs that } \\
\text { succeeded }\end{array}$ & $\begin{array}{l}r_{s}=-0.18, n=34 \\
P=0.32\end{array}$ & $\begin{array}{l}r_{s}=-0.24, n=34 \\
\quad P=0.17\end{array}$ & $\begin{array}{l}r_{s}=-0.12, n=34 \\
P=0.52\end{array}$ & $\begin{array}{l}r_{s}=-0.32, n=34 \\
P=0.07\end{array}$ \\
\hline $\begin{array}{l}\text { Number of Great Tit young that } \\
\text { fledged }\end{array}$ & $\begin{array}{l}r_{s}=-0.24, n=34 \\
P=0.20\end{array}$ & $\begin{array}{l}r_{s}=-0.24, n=34 \\
\quad P=0.18\end{array}$ & $\begin{array}{l}r_{s}=-0.09, n=34 \\
\quad P=0.61\end{array}$ & $\begin{array}{l}r_{s}=-0.32, n=34 \\
\quad P=0.07\end{array}$ \\
\hline $\begin{array}{l}\text { Percentage of successful Great Tit } \\
\text { pairs }\end{array}$ & $\begin{array}{l}r_{s}=-0.24, n=23 \\
P=0.27\end{array}$ & $\begin{array}{l}r_{s}=-0.61, n=14 \\
\quad P<0.05\end{array}$ & $\begin{array}{l}r_{s}=-0.63, n=16 \\
\quad P<0.01\end{array}$ & $\begin{array}{l}r_{s}=-0.94, n=4 \\
P=0.06\end{array}$ \\
\hline
\end{tabular}

Each block contains 4 nest boxes: Control S, Control L, SL and LS. In this study, a maximum of three House Sparrows could breed in a block
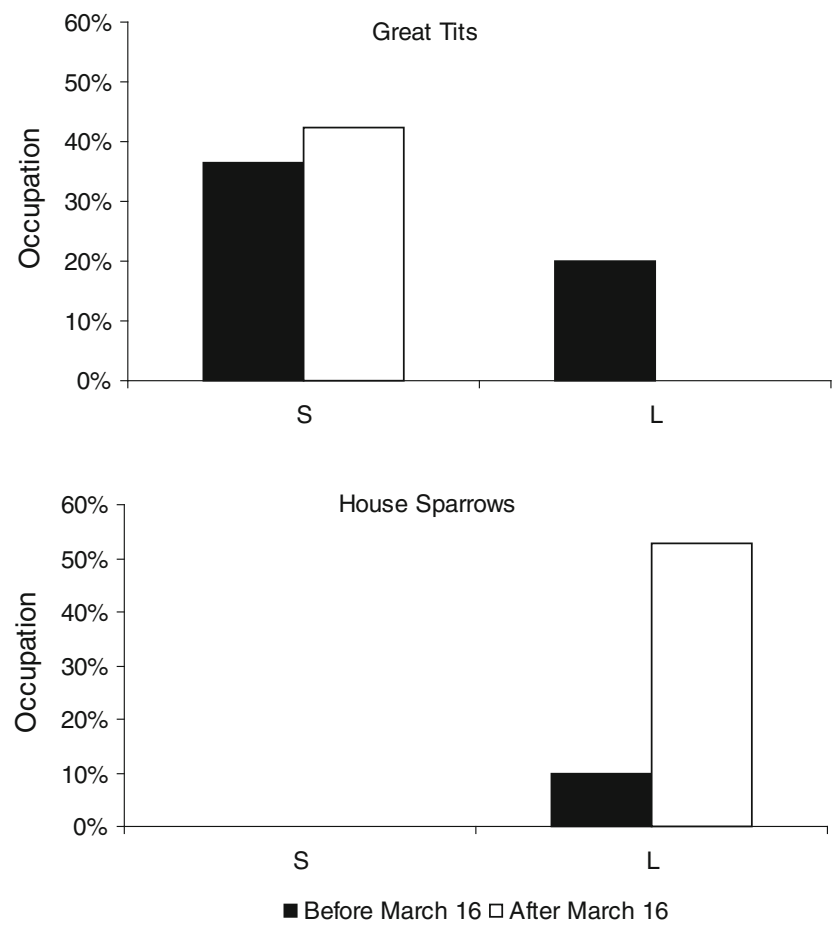

Fig. 2 Comparison of occupation of nest boxes by Great Tits and House Sparrows in $S$ and $L$ entrance nest boxes before (black) and after (white) March 16 during the 2009 breeding season

Occupation of nest boxes from the control groups ( $\mathrm{S}$ and $\mathrm{L}$ nest boxes)

More nest boxes were occupied by Great Tits in the $\mathrm{S}$ $(48.8 \%)$ than the $\mathrm{L}(20.0 \%)$ nest boxes $(z=3.73$, $n 1=41, \quad n 2=40, \quad P<0.001)$ throughout the entire breeding season (Fig. 2). Great Tits occupied the $\mathrm{S}$ nest boxes equally both before and after March $16(z=0.02$, $n 1=41, n 2=26, P=0.83)$; whereas they occupied more (marginally significant) L nest boxes before March $16(z=1.92 n 1=40, n 2=24, P<0.06)$ (Fig. 2), when fewer House Sparrow were breeding.
As expected, House Sparrows occupied only L nest boxes $(47.5 \%$ ) and none of the $S$ nest boxes (Fig. 2). They also occupied significantly more $\mathrm{L}$ nest boxes after March 16 than before it $(z=3.80 n 1=40, n 2=36, P<0.001)$. Comparing the number of Great Tit and House Sparrow pairs breeding in the $\mathrm{S}$ and $\mathrm{L}$ nest boxes throughout the entire study period, Great Tits occupied more $\mathrm{S}$ nest boxes and House Sparrows more L nest boxes $\left(\chi^{2}=32.34\right.$, $d f=1, P<0.0001)$.

Seasonal variation in occupation of nest boxes with experimentally altered entrance sizes (SL and LS nest boxes)

Having found that Great Tits occupied more $\mathrm{S}$ nest boxes and House Sparrows more L nest boxes during the 2009 breeding season, we then examined whether this pattern would continue after we had experimentally switched the entrance sizes in the SL (from S to L) and LS (from L to S) on March 16 (Fig. 3). The number of Great Tit pairs breeding in the SL and LS significantly differed before and after March 16, with more Great Tit pairs breeding in the SL before March and in the LS after March $16\left(\chi^{2}=17.61, d f=1, P<0.0001\right)$; that is, the Great Tits bred more in the nest boxes with smaller entrances.

The number of House Sparrow pairs breeding in the SL and LS significantly differed before and after March 16 $\left(\chi^{2}=31.00, d f=1, P<0.0001\right)$, with House Sparrow pairs breeding only in LS nest boxes before March 16 and only in SL ones after March 16.

\section{Breeding success}

Number of young fledged per laying pair was lower in Great Tit pairs breeding in large ( $\mathrm{L}+\mathrm{SL}$ combined) than in small $(\mathrm{S}+\mathrm{LS}$ combined) entrance nest boxes after 
March 16; whereas no differences were found between laying date, clutch size, brood size, number of young, percentage of hatching success, and percentage of young fledged before or after March 16 (Table 2).

Nest boxes used by both species

Seventy-four percent ( $n=27)$ of nest boxes occupied by Great Tits in the L and SL groups before March 16 were later occupied by House Sparrows. Of them, 6 of the 12 Great Tits pairs that laid eggs in the $\mathrm{L}$ and $\mathrm{S}$ nest boxes failed to fledged young due to the House Sparrows evicting them, and another 8 Great Tit built nests but did not lay eggs because of the House Sparrows. House Sparrows bred similarly in nest boxes that had been first occupied by Great Tits in the SL $(68.4 \%)$ and L groups $(87.5 \%)$ (Fisher's exact test $P=0.32$ ).

After the LS nest boxes entrances were switched on March 16, Great Tits occupied $27.3 \%(n=11)$ of the LS nest boxes that had been previously occupied by House Sparrows before March 16. Great Tits only occupied nest boxes used by House Sparrows when the entrance size was reduced from $\mathrm{L}$ to $\mathrm{S}$, which prevented House Sparrows from entering.
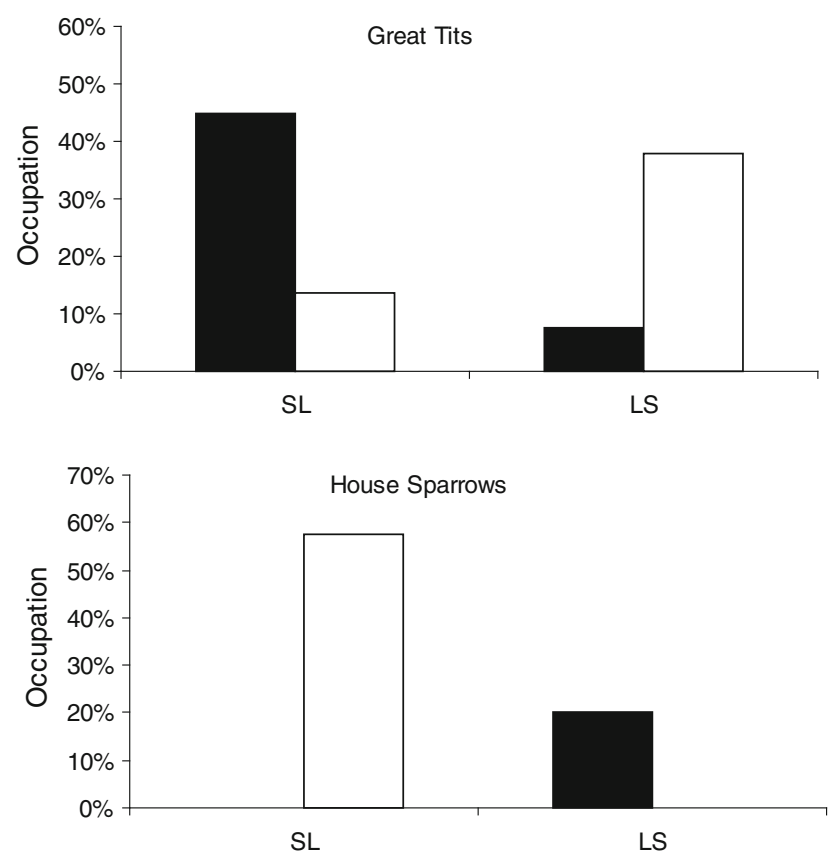

- Before March 16 after March 16

Fig. 3 Comparison of occupation of Great Tits and House Sparrows in the $S L$ and $L S$ entrance nest boxes types before (black) and after March 16 (white) 2009

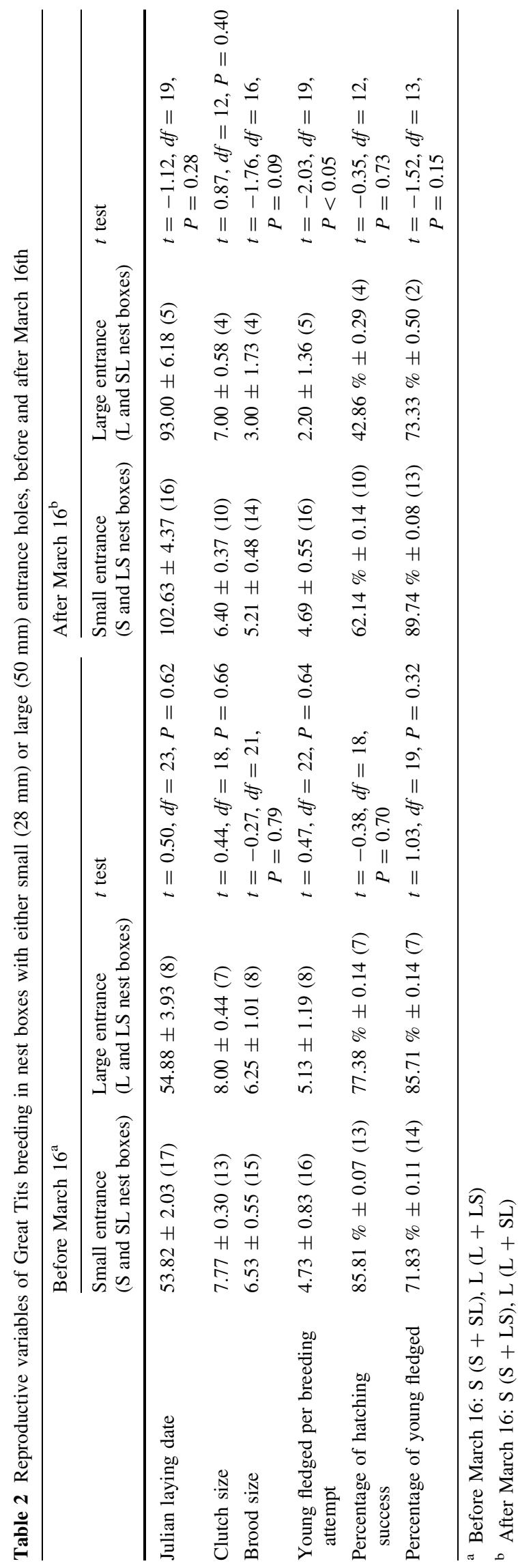




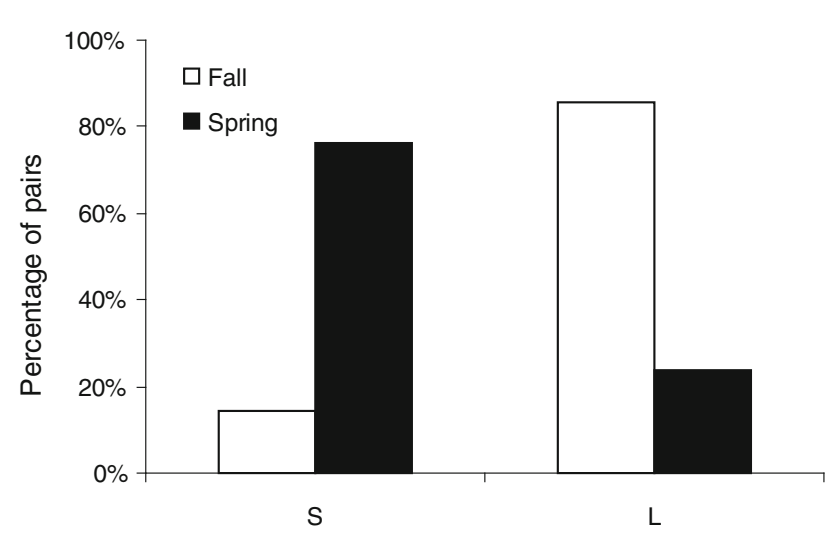

Fig. 4 Comparison of percentage of Great Tit laying pairs breeding in $S(28 \mathrm{~mm})$ and $L(50 \mathrm{~mm})$ entrance nest boxes during the autumn (October 1, 2008 to January 1, 2009) and spring (February 1, to Dec 1, 2009)

\section{Fall versus spring}

Some Great Tit pairs bred in the fall, whereas no House Sparrows did. The percentage of Great Tits breeding in $\mathrm{L}$ nest boxes was significantly higher than in $\mathrm{S}$ nest boxes in the autumn than in spring $2009(z=2.72, n 1=34$, $n 2=7, P<0.01$ ) (Fig. 4).

\section{Discussion}

In this study, both the occupation of nest boxes and the breeding success of the smaller species, Great Tits, were affected by the larger House Sparrows. Significantly fewer Great Tits bred in the large- than small-entrance nest boxes, even though the former were available. In the present study, even though House Sparrows did not occupy all the nest sites, Great Tits still avoided the large-entrance nests. Great Tit pairs breeding in large-entrance nest boxes fledged fewer young than pairs breeding in small-entrance nest boxes. During the winter, Blue Tits also avoid cavities that Great Tits can enter, even when plenty of unoccupied cavities are available (Dhondt and Eyckerman 1980). In an aviary experiment, Kempenaers and Dhondt (1991) found that, when alone, Blue Tits preferred roosts with larger entrances, but switched to small-entrance nest boxes when Great Tits were added to their aviary.

Occupation by the experimental groups (SL and LS) differed, with Great Tits occupying the nest boxes with the small entrances more often than those with large entrances; whereas they bred in the control small-entrance nest boxes equally throughout the breeding season. During the first part of the breeding season, Great Tits bred more in largeentrance nest sites than in the second part of the season, probably because House Sparrows initiated breeding later. House Sparrows were also observed breeding more after
March 16 than before that date, not only in the nest boxes but also in natural cavities at the study sites (Shai Halevi, personal communication). Furthermore, during the autumn, when House Sparrows inhabit communal roosts and do not breed or use nest boxes as roosts in Israel, Great Tits bred in more large-entrance boxes than in small-entrance boxes.

In Europe, small passerines that migrate and arrive at breeding sites together with larger resident birds are sometimes not able to breed at all if nest sites are lacking (Gustafsson 1988; Merilä and Wiggins 1995). In comparison, in our system, both species are resident and the smaller species initiates breeding earlier than the larger ones. Once the larger species initiates breeding, the smaller species needs to adjust accordingly. The size of the bird is probably more important when defending nest sites than the time of breeding, as the larger species can evict the smaller one at any time.

In this study, $74 \%$ of Great Tits that built nests in the $\mathrm{L}$ and SL groups were later evicted by House Sparrows during the second part of the breeding season, half of them through direct interference competition. Great Tits also used House Sparrow nests in the LS treatment after the entrance size had been reduced, but no nests in the L group, demonstrating that the presence of House Sparrows, and not a difference in preference for a particular nest box entrance size, was the reason for their lower occupation by Great Tits. In the only other study that experimentally switched nest box entrances during the breeding season, albeit on a very small scale (7 nests only), van Balen et al. (1982) found that the smaller species bred in the smaller entrance nests successfully but failed to do so in the largeentrance nests, due to the larger species expelling them from the nest boxes. In an observational study, the larger European Starlings (Sturnus vulgaris) were also found to reduce breeding success of the smaller Eurasian Nuthatches (Sitta europaea), by usurping the latter's cavities (Nilsson 1984).

Not only was the occupation of nest sites by Great Tits influenced by House Sparrows but so too was their breeding success. During the breeding season, Great Tits occupied the randomized blocks regardless of House Sparrow occupation in both the small- and large-entrance nest boxes, whereas House Sparrow occupation was negatively correlated with percentage of successful Great Tit pairs both in large-entrance nest boxes before and after March 16, and in small-entrance nest boxes after March 16. Not only did the Great Tits avoid breeding in largeentrance nest boxes but they also had higher breeding success in areas with fewer House Sparrows. In largeentrance nest boxes, some Great Tits were evicted by House Sparrows, which then used these nest boxes for breeding. Moreover, even though House Sparrows could not enter the small-entrance nest boxes, they nonetheless 
negatively affected the percentage of successful Great Tit pairs after March 16, when the House Sparrows bred. We did not observe nest boxes systematically, but House Sparrows were seen attacking Great Tits in nest boxes with both small and large entrances. House Sparrows may fight with Great Tits over cavities for later use, even those they are currently not able to enter, because Syrian Woodpeckers (Dendrocopos syriacus) frequently enlarge cavity entrances, most of which the Woodpeckers do not use for breeding (Charter et al. 2010b). Alternatively, House Sparrows may be territorial to other cavity breeders. Great Tits breeding near House Sparrows may thus be attacked more because of the location of their cavity near House Sparrow nests. Harassment by House Sparrows may therefore hinder food provision to the young Great Tits. Forsman et al. (2008) also found decreased success of the smaller competitor with increased densities of the larger competitor, but, unlike this study, densities in that study were higher in locations with larger competitors because density cues provided by the larger species were used by the smaller ones to determine habitat quality, and thus facilitated habitat selection and investment decisions.

Any differences in occupation of nest boxes and breeding success by Great Tits were probably not due to environmental differences, because the nest boxes were equally distributed in the randomized blocks. There are two possibilities that may account for the difference: Great Tits may breed in more small-entrance than large-entrance nest boxes because of interference competition by House Sparrows; or they may simply prefer small-entrance nest boxes over large-entrance ones. During the spring, it is probable that the Great Tits bred in the small-entrance nest boxes to avoid competition with the larger House Sparrows, but during the autumn, when the latter do not breed, the Great Tits bred in the larger-entrance nest boxes. In the absence of potential competitors, cavities with largeentrances may actually be preferred, as found in winter roosts (Dhondt and Eyckerman 1980; Kempenaers and Dhondt 1991), and be advantageous to smaller species. For example, Great Tits are able to enter the large entrances significantly faster than small entrances (Charter, unpublished data), which may decrease their chances of detection by potential predators (mainly avian). Alternatively, large entrances may increase predation risk, as more predators (e.g. mice, rats, snakes) can enter the larger nest boxes. At the study site, however, nest predation of cavities is very low (Charter et al. 2011), and it is more likely that predation is greatest outside the cavities, so a larger hole enabling swifter entrance may contribute to decreasing detection by other predators, as mentioned above. Unlike in Europe, competition for cavities in this study is mainly during the breeding season, because cavities are used less frequently as roosts by both species in the autumn and winter in Israel. House Sparrows may thus be less territorial around nest boxes during the fall, allowing the smaller Great Tits to use them.

In this study, we have shown how interspecific competition for nest sites affects the occupation and breeding of smaller species during the breeding season. It is also the first study to demonstrate how the intensity of competition varies during the breeding season. Competition is probably species-specific, and can be highly complex when species that compete over nest sites also compete over food (Dhondt 1989), and in some cases the large nest site competitor may also prey on the smaller species (Hakkarainen and Korpimäki 1996; Charter et al. 2010b). Due to difficulties in experimentally manipulating more than one species, competition for nest sites between birds still remains a subject mainly investigated in small passerines. Large passerines are able to oust smaller passerines from nest sites when such sites are in short supply, but it still remains unclear as to whether this also holds true for large species of cavity breeders (raptors, corvids, etc.; Charter et al. 2010b). Using data from this and similar studies on cavity-nesting community webs (Blanc and Walters 2007, 2008) may shed new light on the interactions between cavity breeders of all sizes, both competitive and predatory.

Acknowledgments We thank the residents of Moshav Ram-On for their assistance. Special thanks to Shai Halevi. Hava Ravid, Uri Ravid, and Daniel Berkowic for technical assistance in the field, to Arnon Lotem and Gadi Katzir for advice, to André Dhondt and Shai Markman for comments on the manuscript, and to Naomi Paz for editorial assistance.

\section{References}

Barba E, Gil-Delgado JA (1990) Competition for nest-boxes among four vertebrate species: an experimental study in orange groves. Ecography 13:183-186

Blair RB (1996) Land use and avian species diversity along an urban gradient. Ecol Appl 6:506-519

Blanc L, Walter JR (2008) Cavity nest-webs in a longleaf pine ecosystem. Condor 110:80-92

Blanc L, Walters JR (2007) Cavity-nesting community webs as predictive tools: where do we go from here? J Ornithol 148:417423

Cam E, Nichols JD, Sauer JR, Hines JE, Flather CH (2000) Relative species richness and community completeness: birds and urbanization in the mid-Atlantic states. Ecol Appl 10:1196-1210

Chamberlain DE, Toms MP, Cleary-McHarg R, Banks AN (2007) House sparrow (Passer domesticus) habitat use in urbanized landscapes. J Ornithol 148:453-462

Charter M, Izhaki I, Leshem Y (2010a) Effects of the risk of competition and predation in large secondary cavity breeders. J Ornithol 151:791-795

Charter M, Leshem Y, Halevi S, Izhaki I (2010b) Nest box use by great tits in semi-arid rural residential gardens. Wilson $\mathrm{J}$ Ornithol 122:604-608

Charter M, Izhaki I, Leshem Y (2011) Predation or facilitation? An experimental assessment of whether generalist predators affect the breeding success of passerines. J Ornithol 153:533-539 
Clergeau P, Jokimäki J, Savard J-PL (2001) Are urban bird communities influenced by the bird diversity of adjacent landscapes? J Appl Ecol 38:1122-1134

Crooks KR, Suarez AV, Bolger DT (2004) Avian assemblages along a gradient of urbanization in a highly fragmented landscape. Biol Conserv 115:451-462

Dhondt AA (1977) Interspecific competition between great and blue tit. Nature 268:521-523

Dhondt AA (1989) Ecological and evolutionary effects of interspecific competition in tits, Parus spp. Wilson Bull 101:198-216

Dhondt AA (2010) Effects of competition on great and blue tit reproduction: intensity and importance in relation to habitat quality. J Anim Ecol 79:257-265

Dhondt AA, Adriaensen F (1999) Experiments on competition between great and blue tit: effects on blue tit reproductive success and population processes. Ostrich 70:39-48

Dhondt AA, Eyckerman R (1980) Competition and the regulation of numbers in great and blue tits. Ardea 68:121-132

Forsman JT, Hjernquist MB, Taipale J, Gustafsson L (2008) Competitor density cues for habitat quality facilitating habitat selection and investment decisions. Behav Ecol 19:539-545

Germaine SS, Rosenstock SS, Schweinsburg RE, Richardson WS (1998) Relationships among breeding birds, habitat, and residential development in greater Tuscon, Arizona. Ecol Appl 8:680-691

Gustafsson L (1987) Interspecific competition lowers fitness in the collared flycatcher Ficedula albicollis: an experimental demonstration. J Anim Ecol 68:291-296

Gustafsson L (1988) Inter- and intraspecific competition for nestentrances in a population of the collared flycatcher Ficedula albicollis. Ibis 130:11-15

Hakkarainen H, Korpimäki E (1996) Competitive and predatory interactions among raptors: an observational and experimental study. Ecology 77:1134-1142

Hedblom M, Söderström B (2012) Effects of urban matrix on reproductive performance of Great Tit (Parus major) in urban woodlands. Urban Ecosyst 15:167-180

Keddy PA (1989) Competition. Chapman and Hall, London

Kempenaers B, Dhondt AA (1991) Competition between blue and great Tit for roosting sites in winter: an aviary experiment. Ornis Scand 22:73-75

Loeb SC, Hooper RG (1997) An experimental test of interspecific competition for red-cockaded woodpecker cavities. J Wildl Manag 61:1268-1280
Löhrl H (1977) Nistökologische und ethologische Anpassungserscheinungen bei Höhlenbrütern. Vogelwarte 29:92-101

Marzluff JM (2001) Worldwide urbanization and its effects on birds. In: Marzluff JM et al (eds) Avian ecology and conservation in an urbanizing world. Kluwer, Dordrecht, pp 19-38

Maurer BA (1984) Interference and exploitation in bird communities. Wilson Bull 96:380-395

Menge BA, Sutherland JP (1976) Species diversity gradients: synthesis of the roles of predation, competition, and temporally heterogeneity. Am Nat 110:351-369

Merilä J, Wiggins DA (1995) Interspecific competition for nest holes causes adult mortality in the collared flycatcher. Condor 97:445450

Miller JR, Hobbs RJ (2002) Conservation where people live and work. Conserv Biol 16:330-337

Minot EO (1981) Effects of interspecific competition for food in breeding blue and great tits. J Anim Ecol 50:375-385

Minot EO, Perrins CM (1986) Interspecific interference competitionnest sites for blue and great tits. J Anim Ecol 55:331-350

Nilsson SG (1984) The evolution of nest-site selection among holenesting birds: the importance of nest predation and competition. Ornis Scand 15:167-175

Reynaud PA, Thioulouse J (2000) Identification of birds as biological markers along a neotropical urban-rural gradient (Cayenne, French Guiana), using co-inertia analysis. J Environ Manag 59: 121-140

Scheiner SM, Gurevitch J (2001) Design and analysis of ecological experiments, 2nd edn. Oxford University Press, New York

Schoener TW (1983) Field experiments on interspecific competition. Am Nat 102:240-285

Slagsvold T (1978) Competition between the great tit Parus major and the pied flycatcher Ficedula hypoleuca: an experiment. Ornis Scand 9:46-50

Strubbe D, Matthysen E (2009) Experimental evidence for nest-site competition between invasive ring-necked parakeets (Psittacula krameri) and native nuthatches (Sitta europaea). Biol Conserv 142:1588-1594

van Balen JH, van Booy CJH, van Franeker JA, Osieck ER (1982) Studies on hole-nesting birds in natural nest sites. Availability and occupation of natural nest sites. Ardea 70:1-24

Wiens JA (1989) The ecology of bird communities, vol 2; processes and variations. Cambridge University Press, Cambridge

Yavin S (1987) Nest site selection of the great tit (Parus major terraesanctae). MSc thesis, Tel Aviv University 